\title{
Crocodile Bread As A Ceremonial Marriage Food: Symbolism For The Betawi Ethnic Group (Study Case In Setu Babakan)
}

\author{
Herra Herryani $^{1}$, Tiurma Sinaga ${ }^{2}$, Himawan Brahmantyo ${ }^{3}$ \\ 1 Akademi Pariwisata Indonesia Jakarta, herra_herryani@yahoo.co.id \\ 2 Department of Community Nutrition, Faculty of Human Ecology, Jl. Lingkar Akademik, \\ kampus IPB Darmaga, Bogor 16680, s_tiurmav@ hotmail.com \\ 3 Sekolah Tinggi Pariwisata Trisakti Jl. ikpn tanah kusir Bintaro Jakarta 12330, \\ himawanbrahmantyo@stptrisakti.ac.id
}

\begin{abstract}
The purpose of this study was to assess the significance of bread crocodiles as symbols for indigenous Betawi people in their wedding processions. The method used in the study was descriptive and qualitative by in-depth interview and observation. The study was conducted in Setu Babakan, Betawi Cultural Village, Srengseng Sawah, South Jakarta. Items carried by the groom in the wedding ceremonies of Betawi Moslems are the dowry, a miniature mosque, two pieces of crocodile bread, Betawi traditional cake and kekudang (the bride's favourite things, such as clothing, shoes, salted fish, cookies or crackers). Crocodile bread is a symbol of loyalty because crocodiles are reptiles that are monogamous: the female pairs with the same mate for life, and has a nest that is fixed. The philosophical meaning embodied in the crocodile bread is spouse fidelity, through the generations of children and grandchildren, as well as having a fixed residence. Crocodiles are brave animals, and they can live in two worlds (on land and in the water). The bread is used as a symbol of the hope that households become resilient and able to survive anywhere. The crocodile being made of bread started in the Dutch colonial era. Nowdays, with changing times and the advancement of technology, crocodile bread is increasingly made of sweet bread dough, and also tends to contain chocolate, cheese or strawberry; it can now be readily consumed by the bride's family. With the progress of time, there is a shift; a growing sense that the crocodile bread is a symbol of wealth because bread is considered an expensive food. Usually the crocodile-shaped bread is about 50 centimeters in length, although sometimes as much as one metre, and is carried by the groom at the wedding ceremony. The bread is made into a pair of crocodiles, representing the bride and groom. The bride's bread symbolises crocodile females and includes a little crocodile that is placed on the back or side of the female crocodile. This little crocodile is intended to signify that the newly married family will be blessed with a child as the family successor. At the end of the wedding ceremony, the crocodile bread is usually given to any unmarried sisters, with the hope that they will get married soon. We should preserve and maintain our culture, and let it be known by other nations.
\end{abstract}

Keywords: Betawi ethnic, crocodile bread, philosophy of crocodile bread,

\section{INTRODUCTION}

Every ethnic group in Indonesia has its own customs or culture. The ceremonies of a given culture, mark the path of a person's life and include ritual (often invoking safety or good fortune) associated with pregnancy, birth, marriage, and death. There is always food served as part of the customs of such ceremonies. This food can have a unique philosophical meaning for the particular ethnic group. Most members of the Betawi community carry on ceremonial customs only in token observance of inherited tradition, but the symbolic meaning of bread crocodiles is a poorly understood part of their marriage ceremonies.

Symbol marriage is kind of materials or goods that is characteristic or identical in every celebration or wedding receptions and it is always present in the wedding ceremony. Betawi traditional wedding symbol using the conducting wedding, it is one bread formed crocodile or better known as bread crocodile. Originally, the crocodile symbols were made of wood, and even when the crocodiles later became made from bread the texture was hard and the bread had no taste, so it was not usually eaten. In Indonesia, animals crocodile identical to the negative example "blackguard" or "play boy". The term is synonymous with people who like playing love with other people, but the Betawi people assume crocodile bread as a symbol of loyalty to the couple. Crocodile bread is always available in 
each Betawi wedding events. Betawi culture is the acculturation of Javanese, Sundanese, Bugis, Malay, Portuguese and Dutch nation, and therefore contributes to the culture, customs and food.

The general objective of this study was to examine in more depth about crocodile bread which became a symbol of indigenous Betawi people conducting marriage through interviews with sources who have knowledge of the crocodile bread as conducting Betawi wedding. And The specific objective of this study was : to find out the background and philosophy of crocodile bread used as the conducting the Betawi traditional marriage, and to determine the crocodile bread as conducting wedding in relation with social status in society bridegroom.

\section{METHODS}

\section{Design and Time}

The method used in the study was descriptive and qualitative by in-depth interview with snowball technique and observation. Observations carried out to see how to make crocodile bread at the area production in Betawi community, and to see the wedding that that use crocodile bread as conducting weddings. The study was conducted from February to July 2015 in Setu Babakan, Betawi Cultural Village, Srengseng Sawah, South Jakarta. Regional Setu Babakan Betawi Cultural Village has been set by the Jakarta regional government to preserve Betawi culture.

\section{Informant research}

Informant research is elected speaker like Indigenous Elders Betawi, Cultural Betawi and Observer Betawi Culture and Betawi Society are still using bread crocodile as conducting wedding.

\section{RESULT AND DISCUSSION}

\section{Profile of Setu Babakan}

Setu Babakan or Lake Babakan is located in Srengseng Sawah, Jagakarsa sub-district, South Jakarta, Indonesia serves as the center of Betawi Cultural Village, an area that is maintained to keep the cultural heritage of Jakarta, the Betawi culture. Setu Babakan or an artificial lake with area of 32 hectares $\left(32.000 \mathrm{~m}^{2}\right)$ where the water comes from the Ciliwung River. It is currently used for fishing at surrounding residents. Setu Babakan is also a place for water recreation such as water bike, and biking around the edge of the Setu. Setu Babakan communities still maintain the culture and way of life Betawi ethnic, fishing, farming, travel far from home, make handicrafts, and make food Betawi.

Setu Babakan is a residential neighborhood that has the feel is still strong in terms of culture, arts, snacks, clothing, religious routines, as well as the shape of Betawi house. This village inhabited by at least 3,000 households. Most of the households are people who have hereditary Betawi live in the area. Setu Babakan considered to still retain and preserve Betawi culture, such as buildings, dialect, dance, music, art and drama. Setu Babakan also is one of the selected object Pacific Asia Travel Association (PATA) as a travel destination for participants PATA conference in Jakarta in October 2002. The Government Indonesia and Betawi people start to try to pioneer and develop the village as a worthy cultural heritage area visited by tourists.

In Setu Babakan village, there is a shop that much selling typical foods Betawi, such Ketoprak, ketupat laksa, egg crust, ketupat sayur (vegetable), arum manis (candy), soto Betawi, chicken noodles, noodle soup, crocodile bread, bir pletok (beer), nasi uduk, kue apem, fried bean sprouts, and tahu gejrot (tofu). Tourists visiting the Setu Babakan can also watch cultural performance Betawi, like cokek dance, mask dance, qasida, marawis, seni gambus, lenong, tanjidor, gambang kromong, and ondel-ondel are often performed on an outdoor stage measuring 60 meters square every saturday and sunday. Besides art show, visitors can also see processions of Betawi culture, such as wedding ceremonies, sunat, akikah, complete the Qur'an (khatam Al-Qur'an) and 7 months of pregnancy celebration, or exercise dance and silat Betawi that is Beksi. Tourists visiting the home court of the community, usually will given the fruit as a sign of respect. If tourists are interested in picking and intend to bring home the fruit, visitors can buy it. Fruits are available in the place include star fruit, rambutan, buni, guava, dukuh, menteng, gandaria, noni, kecapi, durian, jengkol, kemuning, krendang. 


\section{Profile of Informant Research}

There were 10 persons as informat research. Most of their age were 51 years to 60 years. All of them live in a tourist village. They were an observers for Betawi culinary and Betawi culture. They have direct experience of undergoing Betawi traditional wedding ceremony. All of interviewees who had married, have a family, and ever to marry their children using crocodile bread as conducting wedding in the area of Tourism Village Setu Babakan Betawi.

\section{Betawi Culture in Wedding Ceremony}

All of informant research know the culture in the wedding betawi because they are in the neighborhood Setu Babakan Betawi tourist village that retains customs Betawi community in social life. Based on the interview, items carried by the groom in the wedding ceremonies of Betawi Moslems are the dowry, a miniature mosque, two pieces of crocodile bread, Betawi traditional cake and kekudang (the bride's favourite things, such as clothing, shoes, salted fish, cookies or crackers). They know this is because the culture of marriage is still maintained in public life in Setu Babakan village.

Seven person from informants know the meaning and significance of crocodile bread of Betawi conductivity wedding, and three resource persons only know that the crocodile bread as a symbol of the conducting weddings Betawi. They know only as hereditary customs that should be implemented. Meaning less deeply understand because they only followed the tradition that has been carried to the next generation. The speakers who know the meaning crocodile bread as a symbol of loyalty to the spouse, the symbol of life balance and should always be included in every wedding.

Answer of ten speakers know that the philosophy embodied in the symbol of bread crocodile as conducting Betawi wedding. In the Betawi community, crocodile bread commonly used by Betawi community as a default in the wedding procession. Originally, the crocodile symbols were made of wood, and even when the crocodiles later became made from bread the texture was hard and the bread had no taste, so it was not usually eaten. Crocodile bread must be always bring in seserahan marriage in community Betawi. With the progress of time, there is a shift; a growing sense that the crocodile bread is a symbol of wealth because bread is considered an expensive food.

Based on interviews with sources explained that the philosophical meaning embodied in the crocodile bread is spouse fidelity, through the generations of children and grandchildren, as well as having a fixed residence. A pair of crocodile bread is offering or form "seserahan" the groom to the bride. Crocodile bread hence not be eaten, but only display it on the table and sometimes often pasted on the wall near the altar.

Bread crocodile in the world of the concept of Betawi community is used to glorify, and white crocodile as a good sign for marriage. White crocodile is a mythical animal sacred river for the Betawi. A pair of crocodile bread is a symbol of a spiritual force that will protect the couple married at the time wedding party took place. Another opinion says, crocodile bread is a symbol of loyalty because crocodiles are reptiles that are monogamous: the female pairs with the same mate for life, and has a nest that is fixed. crocodiles usually mate only once in a lifetime or monogamous and have nests are fixed and do not move where. Based on interviews with sources, the crocodile being made of bread started in the Dutch colonial era. Nowdays, with changing times and the advancement of technology, crocodile bread is increasingly made of sweet bread dough, and also tends to contain chocolate, cheese or strawberry; it can now be readily consumed by the bride's family. 


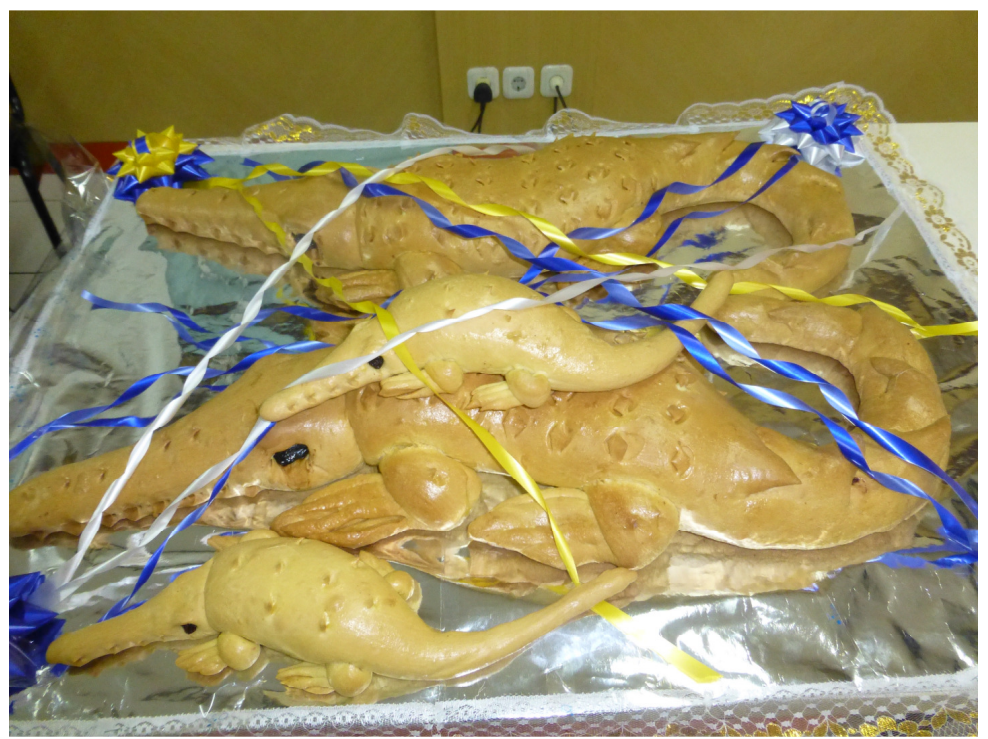

Figure 1. Crocodile Bread

Answer informant only know crocodile bread as a symbol of conducting wedding Betawi. There was only one informant said that crocodile bread usually serve with crab bread as conducting wedding Betawi. According to one informant people, the crab bread have a meaning that if the Betawi people will visit to the family home, they should bring food so it does not bother the host visited. At the time of bringing food in large quantities, the one hand that brought will tilt (hands are not balanced). Its meaning can be like to the same as the way crabs walk sideways animals. In addition, a speaker also explained that crab animal life groups and reproduce by laying eggs. Its means for the bride and groom are expected after marriage, the family life can be lived with the people in the environment where they lived and was given a lot of children. Crocodiles are brave animals, and they can live in two worlds (on land and in the water).

The bread is used as a symbol of the hope that households become resilient and able to survive anywhere. Usually the crocodile-shaped bread is about 50 centimeters in length, although sometimes as much as one metre, and is carried by the groom at the wedding ceremony. The bread is made into a pair of crocodiles, representing the bride and groom. The bride's bread symbolises crocodile females and includes a little crocodile that is placed on the back or side of the female crocodile. This little crocodile is intended to signify that the newly married family will be blessed with a child as the family successor. At the end of the wedding ceremony, the crocodile bread is usually given to any unmarried sisters, with the hope that they will get married soon.

\section{CONCLUSION}

Betawi traditional marriage, never left the crocodile bread as a symbol of conducting weddings. In the wedding ceremonies of Betawi Moslems are the dowry, a miniature mosque, two pieces of crocodile bread, Betawi traditional cake and kekudang (the bride's favourite things, such as clothing, shoes, salted fish, cookies or crackers). This is so that the presence of entrenched crocodile bread as a symbol of Betawi wedding can not be separated and it has been handed down to do for Betawi people. The young generation should be able to cultivate and preserve the Betawi culture. Indonesian society should be more proud of the indigenous cultures of Indonesia. The meaning and philosophy of Indonesian culture very well and in accordance with the culture of Indonesian society. Do not let us to lose the original culture or fade due to incoming foreign culture but we should preserve and maintain our culture, and let it be known by other nations.

Crocodile bread is a symbol of loyalty because crocodiles are reptiles that are monogamous: the female pairs with the same mate for life, and has a nest that is fixed. The philosophical meaning embodied in the crocodile bread is spouse fidelity, through the generations of children and grandchildren, as well as having a fixed residence. Crocodiles are brave animals, and they can live in two worlds (on land and in the water). The bread is used as a symbol of the hope that households 
become resilient and able to survive anywhere. The crocodile being made of bread started in the Dutch colonial era. Nowdays, with changing times and the advancement of technology, crocodile bread is increasingly made of sweet bread dough, and also tends to contain chocolate, cheese or strawberry; it can now be readily consumed by the bride's family. With the progress of time, there is a shift; a growing sense that the crocodile bread is a symbol of wealth because bread is considered an expensive food. Usually the crocodile-shaped bread is about 50 centimeters in length, although sometimes as much as one metre, and is carried by the groom at the wedding ceremony. The bread is made into a pair of crocodiles, representing the bride and groom. The bride's bread symbolises crocodile females and includes a little crocodile that is placed on the back or side of the female crocodile. This little crocodile is intended to signify that the newly married family will be blessed with a child as the family successor. At the end of the wedding ceremony, the crocodile bread is usually given to any unmarried sisters, with the hope that they will get married soon.

\section{REFERENCES}

Ardan, S. M., Sjafi'ie, Irwan. H., Saputra, Andi, Yahya, 2000, Siklus Betawi: Upacara dan Adat Istiadat, Lembaga Kebudayaan Betawi bekerjasama dengan Dinas Kebudayaan Propinsi DKI Jakarta.

Departemen Pendidikan dan Kebudayaan. 1996, Makanan, Variasi dan Fungsinya serta Cara Penyajian Pada Masyarakat DKI Jakarta

Lembaga Kebudayaan Betawi, 2004, Tata Cara Perkawinan Adat Betawi

Liliweri, Alo, 2002. Makna Budaya Dalam Komunikasi Antarbudaya, Jakarta: LKiS Yogyakarta.

Saidi, Ridwan, 2011, Potret Budaya Manusia Betawi. Jakarta, Perkumpulan Renaissance Indonesia.

Saidi, Ridwan , 1996, Babad Tanah Betawi, Jakarta, PT. Griya Mega Prima.

Saidi, Ridwan, (2011), Profil Orang Betawi: Asal Muasal, Kebudayaan dan Adat Istiadatnya Jakarta, PT.Guntara Kata.

Shahab, Ali, 2004. Saudagar Baghdag Dari Betawi, Jakarta: Republik.

Zulkifli, M. Roti Buaya sebagai Simbol Pernikahan Adat Betawi. 